\title{
不規則き裂進展に対する確率場を用いた新しいモデル†
}

\section{A New Probabilistic Model for Random Fatigue Crack Growth Based upon a Random Field}

by

\author{
Hiroaki TANAKA *
}

\begin{abstract}
A new probabilistic model describing the random fatigue crack growth is proposed based upon a spatially random differential equation driven by a random field. First, a basic equation to describe the random crack growth is formulated as a system of spatially random differential equations by modeling the random propagation resistance in the well-known Paris law as a homogeneous random field. The probability of failure against the fatigue crack growth is then formulated as a functional integral form by the use of its solution. Next, validity of the proposed model is quantitatively verified by comparing with statistical experimental data reported by Ichikawa et.al. Next, an importance sampling simulation scheme is constructed by the use of the Girsanov theorem to make an efficient esimtation for the probability of failure. A numerical example is finally given, which shows that the proposed simulation scheme can give accurate estimation for extremely small probability of failure.
\end{abstract}

Key words : Fatigue crack growth, Random crack growth, Probabilistic model, Random field, Random differential equation, Monte Carlo simulation, Importance sampling method

\section{1 緒言}

疲労き裂の不規則進展特性を把握することは, 耐疲労 信頼性を向上させる上で重要であり, とりわけ損傷許容 の概念に基づいて設計された部材については，不規則成 長の確率的性質を定量化することが最重要課題であると 言っても過言ではない。このような背景の下に, 疲労き 裂の不規則成長の確率的性質を理論的に解明するための 研究が活発に行われてきた。この中で現在最も広く用い られているのが，経験的に得られたき裂成長則中に不規 則な要因が含ま机ると考える物理的確率モデルである。

市川らは一連の研究 ${ }^{1) \sim 4)}$ の中で, 統計的疲労試験を 通じてき裂成長の統計的性質を実験的に明らかとすると 共に, 周知の Paris 則に基づく物理的確率モデルを構築 し, 理論的側面からの考察を行なってきた. 文献 2) 〜 4) に打いては，Paris則中のき裂進展抵抗が空間的にラン ダムな変動を行なうという基本的仮定の下に構築した確 率モデルにより，実験データの統計的性質をうまく再現 できることを示した。このモデルでは進展抵抗の空間的 変動が離散的と想定されているが, 実際の材料に打ける それは連続であると考える方がより自然である。このよ うな観点から, 石川ら ${ }^{5)}$ は進展抵抗の変動が連続的であ るという仮定に立脚したモデルを提案した。このモデル に招いては, 進展抵抗の変動は基本的には空間的に発生 するものと想定されているが，基本方程式を通常の確率 微分方程式のカテゴリーに納めるために，その空間的変 動が, 事前に推定される解の平均的挙動を通じて時間的
ランダム変動に置き換えられて抢り，この仮定が入力雑 音の性質を特定する上で一種の循環論法的な困難さを引 き起こしている.

これらの問題点を解消するために，著者は文献 6)，7） に打いて，市川らのモデルを連続変動の確率場に置き換 え,さらに石川らのモデルで用いられている確率場を確 率過程に変換するという手順を踏まないモデルのプロト

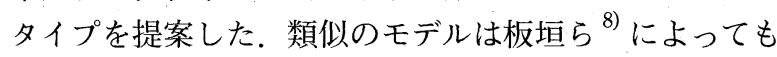
論じられており，き裂の成長の不規則な特性がき裂先端 近傍の材料の微視的ランダム性によって引き起こされる という仮定に立脚する限りに打いては最も自然なモデル であると考えられる。しかしながら，文献 6)〜8）にお いては，モデルに基づく破壊確率の推定に対して，近似 解法あるいは直接的なシミュレーションによる解法のみ が論じられており，極めて微小な破壊確率が要求される 際に対処することが難しい。そそこで本論文では，文献 6), 7) で導入したモデルを確率微分方程式の観点から再構成 し，その統計的疲労試験データとの適合性を検証すると 共に，著者が文献 9)で開発した時間依存型信頼性解析 に適用可能な重点サンプリング法を用い，実用上重要と なる極めて小さな破壊確率を取る時間領域での精度のよ い推定スキームの開発を試みる。

\section{2 モデルの基本概念}

本論文では, 中央貫通き裂あるいは縁き裂などの 2 次 元き裂の, 一定応力振幅の繰り返し負荷下での成長を対 象とし，元の時間変動は周知の Paris 則で記述されるも

$\dagger$ 原稿受理 平成 12 年 4 月 7 日 Received Apr. 7, 2000

* 正 会員 京都大学情報学研究科複雑系科学専攻 个606-8501 京都市左京区吉田本町, Dept. of Applied Analysis and Complex Dynamical Systems, Kyoto Univ., Sakyo-ku, Kyoto, 606-8501 
のとする.すなわち，

$$
\frac{1}{a_{r}} \frac{d a}{d n}=\varepsilon_{0}\left(\frac{\Delta K}{\Delta K_{0}}\right)^{m}
$$

ここで $a$ はき裂長， $\varepsilon_{0}$ は無次元化されたき裂進展抵抗， $\Delta K$ は応力拡大係数の変動幅, $a_{r}$ 打よび $\Delta K_{0}$ はそれ㕴の 参照值である. 応力拡大係数变動幅 $\Delta K$ が, 負荷応力振 幅 $\Delta S$, 有限板幅補正 $F_{I}$, 打よび幾何因子 $\alpha$ を用いて,

$$
\Delta K=\alpha \Delta S \sqrt{\pi a} F_{I}(a)
$$

という形で与えられるものとする. 解析の便宜上無次元 き裂長 $X \equiv a / a_{r}$ を導入し，さらに

$$
\Delta K_{0}=\alpha \Delta S \sqrt{\pi a_{r}}
$$

と設定すれば，式 (1) は次のように書き換えることがで きる。

$$
\frac{d X}{d n}=\varepsilon_{0} g(X), g(X)=\left\{\sqrt{X} F_{I}\left(a_{r} X\right)\right\}^{m}
$$

これまでの多くの研究における基本的な考え方は, 式 (4) 中のき裂進展抵抗 $\varepsilon_{0}$ がランダムな特性を有すると考 えるもので，これに基づく最も簡単なモデルでは $\varepsilon_{0}$ は確 率変数と仮定され, より進んだモデルでは，旮れが時間的 に不規則に変動する確率過程であると仮定されてきた。 しかしながら, 材料の微視的構造の不規則性がき裂進展 抵抗の不規則変動を引き起こすという考方方に立脚する 限り, その変動はき裂先端の位置の関数として記述され ると仮定することが最も自然である。. ${ }^{6)}$ そ) そのために，

$$
\varepsilon_{0}=\frac{\varepsilon}{C(X)}
$$

なる形で無次元確率場 $C(X)$ を導入し, $\varepsilon$ は定数であるも のとして扔く．このとき，一般性を失うことなく $C(X)$ の 平均を 1 に設定することができる.

式 (5) を式 (4) に代入し，スケーリングした時間変数 $t$ $=\varepsilon n$ を用いると，次式を得る.

$$
\frac{d X}{d t}=\frac{g(X)}{C(X)}
$$

このモデリングの原型は板垣らの報告 ${ }^{8)}$ に見られるが, そこではランダム化された進展則を確率微分方程式の一 つとして認識する立場からの議論はなされていない。こ こで注意しなければならないのは，この方程式を確率微 分方程式として見た場合，文献 6)で著者が指摘したよ うに，従属变数が外乱である確率場の位置を指定する変 数を兼ねているという非常に特殊な確率微分方程式であ り，その解の定義について慎重に対応しなければならな いという点である。 そのために，独立变数と従属変数を 入れ替えた，

$$
d T(x)=\frac{C(x)}{g(x)} d x
$$

なる反転方程式を導入し, その解 $T(x)$ を用いて,

$$
X(t) \equiv \inf _{x>x_{0}}\{T(x)>t\}
$$

により式 (6) の解 $X(t)$ を定義するという手法を用いる. ここで $x_{0}$ は初期き裂長であり, 本論文では簡単のためこ れは確定量であるものとする。

本論文では，次節で述べるように，進展抵抗の不規則 変動を記述するために導入した確率場 $C(X)$ が確率 1 で 負の值を取らない場合に議論を限定するため，式 (8) は
解 $T(x)$ の逆写像を用いて次のように表せることになる.

$$
X(t)=T^{-1}(t)
$$

3 不規則き裂成長を支配する基礎方程式

き裂を有する材料の巨視的な均一性が仮定できるもの とすれば, 確率場 $C(x)$ は一様(空間的に定常) と考えて 構わない.さらに，その確率分布は対数正規分布でよく 記述できるという報告 ${ }^{1), 2)}$ に基づき，位置 $x$ を固定する ごとに $C(x)$ は対数正規分布に従うものと仮定する。一様 な対数正規確率場の発生法としては種々の方法が考えら れるが, 本研究では, 平均ゼ口, 分散 $\sigma_{C_{0}}^{2}$ の一様な正規 確率場 $C_{0}(x)$ からの点変換により発生させる方法を取る. すなわち，先に述べたように $C(x)$ の平均を 1 とできるこ とから,

$$
C(x)=\exp \left\{C_{0}(x)-\frac{1}{2} \sigma_{C_{0}}^{2}\right\}
$$

このとき, $C(x)$ の分散 $\sigma_{C}^{2}$ は，

$$
\sigma_{C}^{2}=\exp \left(\sigma_{C_{0}}^{2}\right)-1
$$

で与えられる。

さらに, 解析上の扱い易さと 6 節で述べる効率的シミ ュレーションスキームの構成を念頭に置いて，平均ゼロ の一様正規確率場 $C_{0}(x)$ は, 空間的 Markov 性を有する ものと仮定する。このとき，Doobの定理 ${ }^{10)}$ により， $C_{0}(x)$ の空間的共分散関数は次のような指数関数的減 衰型,

$$
\mathrm{E}\left[C_{0}\left(x^{\prime}\right) C_{0}\left(x^{\prime}+x\right)\right]=\sigma_{C_{0}}^{2} \exp \left(-\frac{|x|}{L_{C}}\right)
$$

となり, $C_{0}(x)$ は次の確率微分方程式の解として与えら れることになる。

$$
\begin{gathered}
d C_{0}(x)=-\frac{1}{L_{C}} C_{0}(x) d x+\sqrt{\frac{2 \sigma_{C_{0}}^{2}}{L_{C}}} d B(x) \\
C_{0}\left(x_{0}\right)=\sigma_{C_{0}} N
\end{gathered}
$$

ここで, $B(x)$ は $B\left(x_{0}\right)$ を確率 1 で満たす Wiener 場，す なわち独立増分を持つ平均ゼ口の正規確率場で,

$$
\mathrm{E}\left[B(x) B\left(x^{\prime}\right)\right]=\min \left(x, x^{\prime}\right)
$$

を満たすものであり, $N$ は $B(x)$ とは独立な標準正規確率 変数である. また, 正定数 $L_{C}$ は無次元化された相関距 離である。

これらの仮定により， $T(x)$ の空間変動を支配する確率 微分方程式として次式を得る.

$$
d T(x)=\frac{\exp \left\{C_{0}(x)-\frac{1}{2} \sigma_{C_{0}}^{2}\right\}}{g(x)} d x, T\left(x_{0}\right)=0
$$

以上をまとめると，式 (13)，(14)，(16) を連立させた空 間変動型の連立確率微分方程式が本提案モデルにおける 不規則き裂成長を記述する基本方程式であり，通常の確 率微分方程式に扔ける独立変数と従属変数の役割が逆と なっていること, およびき裂進展過程をその解の逆関数 により定めるところに特徴がある.

\section{4 破壊確率の定式化}

負荷応力振幅が確定的であるという条件の下に，き裂 長 $X(t)$ が所与の限界長 $x_{c}\left(>x_{0}\right)$ に達したときに部材が破 壞するものと仮定する. 本論文ではき裂進展抵抗の不規 則変動を表す確率場 $C(x)$ が負の值を取らないと仮定して 
いることから,$X(t) \geq x_{c}$ となることと $T\left(x_{c}\right) \leq t$ となるこ とは同值となる。したがって, 時刻 $t$ までに破壊する確 率を $p_{f}(t)$ と記すことにすれば,

$$
p_{f}(t)=P\left(T\left(x_{c}\right) \leq t\right)
$$

が成立する。

反転方程式 (16) を積分すると,

$$
T\left(x_{C}\right)=\int_{x_{0}}^{x_{c}} \frac{\exp \left\{C_{0}(x)-\frac{1}{2} \sigma_{C_{0}}^{2}\right\}}{g(x)} d x
$$

を得るので, $C_{0}(x)$ の区間 $\left[x_{0}, x_{c}\right]$ での挙動が決まればそ れに対応して $T\left(x_{c}\right)$ が定まることになる。ここで，区間 $\left[x_{0}, x_{c}\right]$ に打けるWiener 場 $B(x)$ の全挙動を，

$$
\boldsymbol{B}=\left\{B(x) ; x_{0} \leq x \leq x_{c}\right\}
$$

と表すことにすれば，これは区間 $\left[x_{0}, x_{c}\right]$ で定義された実 数値連続関数全体からなる関数空間(以下簡単のため $C$ と記す）の要素となる。 $C_{0}(x)$ の挙動は, 式 (13), (14) を通じて， B および $N$ おり完全に決定されるので, 結 局 $T\left(x_{c}\right)$ がこれらにより完全に決定されることになる. この関係を次のような汎関数写像の形で表現しておく.

$$
T\left(x_{c}\right)=\mathcal{H}[\boldsymbol{B}, N]
$$

この写像の具体的な評価については, $\boldsymbol{B}$ および $N$ のサン プルを発生させるごとに式 (13)，(16) を数值的に解くと いう手法を用いる。このような写像表現を用いると, 式 (17) で与えられる破壊確率 $p_{f}(t)$ は,

$$
p_{f}(t)=\int_{C \times \mathbb{R}^{1}} U(t-\mathcal{H}[\boldsymbol{b}, n]) d P_{B}(\boldsymbol{b}) d P_{N}(n)
$$

という汎関数積分形で形式的に表現することができる. ここで, $\mathrm{U}(\cdot)$ は単位ステップ関数, $P_{B}$ は空間 $C$ 上に定 義されたWiener 測度, $P_{N}$ は $\mathbb{R}^{1}$ 上に定義された標準 Gauss 測度である。

\section{5 モデルの妥当性についての検討}

ここでは，本論文で構築した確率モデルと実験データ との比較を行ない, 本モデルの妥当性について検討する. 用いるデータは，市川らにより報告されたアルミ合金 2024-T3 に詨する統計的疲労試験データ 1), 2) である。こ のデータは, 幅 $70[\mathrm{~mm}]$ の試験片に発生した中央貫通き 裂に対する疲労試験を同一荷重条件（応力振幅 59.4 $[\mathrm{MPa}]$, 応力比 0.2) 下で 30 本の試験片に対して行ない, その結果を統計的にまとめたものである.

初期き裂半長 $a_{0}$ から成長を開始したき裂が，所定のき 裂半長 $a$ まで達するのに要するサイクル数, いわゆる残 存寿命を $n\left(a ; a_{0}\right)$ と表す. 本提案モデルに基づく, 無次 元き裂長 $x_{0}$ から $x$ までの残存寿命を $T\left(x ; x_{0}\right)$ と表すと, これは確率微分方程式 (16) の解であり, $n\left(a ; a_{0}\right)$ とは,

$$
n\left(a ; a_{0}\right)=\frac{1}{\varepsilon} T\left(\frac{a}{a_{r}} ; \frac{a_{0}}{a_{r}}\right)
$$

なる関係で結ばれることになる。これより， $n\left(a ; a_{0}\right)$ の 変動係数 $\left(\eta_{n}\left(a ; a_{0}\right)\right.$ と記す $)$ は $T\left(a / a_{r} ; a_{0} / a_{r}\right)$ のそれ に等しく,

$$
\eta_{n}\left(a ; a_{0}\right)=\frac{\sqrt{\operatorname{Var}\left[T\left(a / a_{r} ; a_{0} / a_{r}\right)\right]}}{\mathrm{E}\left[T\left(a / a_{r} ; a_{0} / a_{r}\right)\right]}
$$

で与えられることがわかる。

式 (18)に扎いて $x_{c}=a / a_{r}, x_{0}=a_{0} / a_{r}$ とし，式 (12)の
関係および式 (10) を用いると,

$$
\begin{gathered}
\mathrm{E}\left[T\left(\frac{a}{a_{r}} ; \frac{a_{0}}{a_{r}}\right)\right]=\int_{a_{0} / a_{r}}^{a / a_{r}} \frac{d x}{g(x)} \\
\operatorname{Var}\left[T\left(\frac{a}{a_{r}} ; \frac{a_{0}}{a_{r}}\right)\right]=\int_{a_{0} / a_{r}}^{a / a_{r}} \int_{a_{0} / a_{r}}^{a / a_{r}} \\
\times \frac{\exp \left(\sigma_{C_{0}}^{2} e^{-\left|x-x^{\prime}\right| / L_{C}}\right)-1}{g(x) g\left(x^{\prime}\right)} d x d x^{\prime}
\end{gathered}
$$

が得られるので, これらを式 (23) に代入することにより 変動係数 $\eta_{n}\left(a ; a_{0}\right)$ を得ることができる.

Fig. 1 は, 残存寿命 $n(a ; 9.0)$ の変動係数の $a$ 依存性 について市川らのデータとの比較を行なったものである.

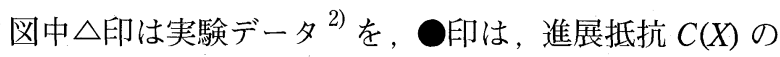
変動係数を $\sigma_{C}=0.25$, 無次元相関距離を $L_{C}=0.04$ と設 定することにより式 (23) から得られる本モデルでの推定 結果を示している. Paris 則のべき指数については $m=$ 2.939 とし ${ }^{1)}$ 式 (2) 中の補正関数としては, 試験片の板 幅を $W$ として，

$$
F_{I}(a)=\sqrt{\sec \left(\frac{\pi a}{W}\right)}
$$

なる関数形を用いてある.' なお，本論文では式 (24) およ び式 (25) から推定される変動係数挙動が実験データによ くフィットするように試行錯誤的に $\sigma_{c}$ および $L_{c}$ の值を 決定するという手法を用いた。この結果から， $a$ の増加 に伴って残存寿命の変動係数が徐々に小さくなっていき, ある一定值に収束していく傾向をよく再現していること がわかる。

次に Fig. 2 は, 残存寿命 $n(23.0 ; 9.0)$ の確率分布関数 について比較を行なったものであり，図中 $\triangle$ 印は㬰験デ 一タ ${ }^{1)}$ を，印は上述のパラメータ設定に基づき本提案 モデルより得られる推定結果を示している。ただし，図 は対数正規確率紙と同等となるように両軸をスケーリン グしており, 図中の $\Phi^{-1}(\cdot)$ は標準正規分布関数の逆関数 を表す。なお，本モデルによる分布関数の推定には，サ ンプル数 10000 のモンテカルロシミュレーションを用い ており，パラメータ $\varepsilon$ は実験データより得られている $\varepsilon_{0}$ の統計的性質と式 (5) から,$C(X)$ の平均が 1 となるよう に定めてある。この結果から，変動係数だけでなく分布

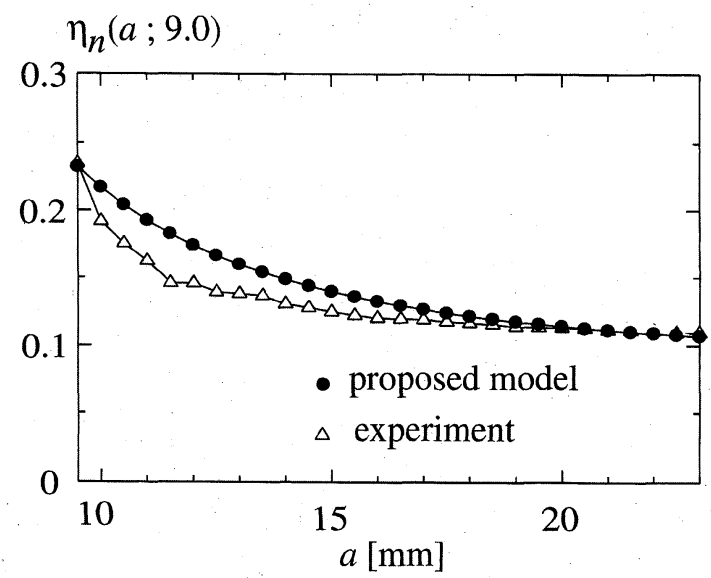

Fig. 1. Coefficient of variation of the residual life. 


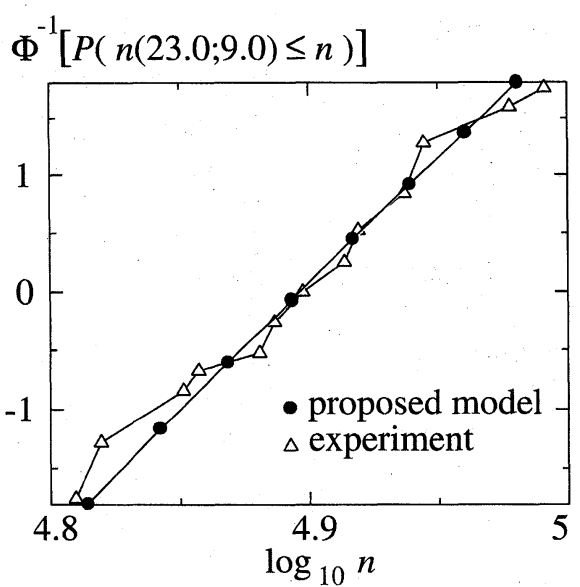

Fig. 2. Probability distribution function of the residual life $n$. $23.0 ; 9.0)$.

特性についても本モデルは実験データの特性をよく表し ているといえ, 疲労き裂の不規則成長を記述するモデル として妥当であると考えられる.

\section{6 重点サンプリング法による破壊確率の効率的評価}

\section{$6 \cdot 1$ 重点サンプリング法の基本原理}

式 (21) を解析的な形で表現することは難しいことか ら，モンテカルロ法に代表される計算機シミュレーショ ンの活用により数值的に評価する必要が生ずる。しかし， 実用的には破壊確率 $p_{f}(t)$ が極めて微小な值を取ること が要求され，モンテカルロ法を単純に適用したのでは莫 大なサンプル数が必要となるため, 何らかの効率化手法 を適用しなければならない，本研究では著者が文献 ${ }^{9)}$ で 構築した時間依存系に対する重点サンプリングシミュレ ーションスキームを適用して効率化シミュレーションス キームを構成する.

重点サンプリング法とは，原確率測度とは異なる確率 測度の下でサンプルを発生させることにより，原確率測 度下では極めて希にしか発生しない破壊領域への到達サ ンプルを多く発生させることにより，シミュレーションの 収束を速める方法である。このために, Wiener 測度 $P_{B}$ および Gauss 測度 $P_{N}$ とそれぞれ互いに絶対連続な確率 測度 $\tilde{P}_{B}, \tilde{P}_{N}$ を導入し, 式 (21) を次のように变形する.

$$
\begin{aligned}
p_{f}(t)=\int_{C \times \mathbb{R}^{1}} U(t & -\mathcal{H}[\boldsymbol{b}, n]) \frac{d P_{B}}{d \tilde{P}_{B}}(\boldsymbol{b}) \frac{d P_{N}}{d \tilde{P}_{N}}(n) \\
& \times d P_{B}(\boldsymbol{b}) d P_{N}(n)
\end{aligned}
$$

ここで $d P_{B} / d \tilde{P}_{B}$ および $d P_{N} / d \tilde{P}_{N}$ は Radon-Nikodym 導 関数である. 式 (27) に基づくモンテカルロ法による破壊 確率の推定值は, 次式となる.

$$
\begin{aligned}
\hat{p}_{f}(t ; J)= & \frac{1}{J} \sum_{j=1}^{J} U\left(t-\mathcal{H}\left[\boldsymbol{B}_{\tilde{P}_{B}}^{(j)}, N_{\tilde{P}_{N}}^{(j)}\right]\right) \\
& \times \frac{d P_{B}}{d \tilde{P}_{B}}\left(\boldsymbol{B}_{\tilde{P}_{B}}^{(j)}\right) \frac{d P_{N}}{d \tilde{P}_{N}}\left(N_{\tilde{P}_{N}}^{(j)}\right)
\end{aligned}
$$

ここで， $\boldsymbol{B}_{\tilde{P}_{B}}^{(j)}, N_{\tilde{P}_{N}}^{(j)}(j=1, \cdots K)$ はそれぞれ確率測 度 $\tilde{P}_{B}, \tilde{P}_{N}$ に従って発生させた $\boldsymbol{B}, N$ の独立サンプル列 である

したがって, 確率測度 $\tilde{P}_{B}, \tilde{P}_{N}$ をうまく選定すること
により，破壊領域に到達するサンプルの発生頻度を高め， その重みを $d P_{B} / d \tilde{P}_{B}, d P_{N} / d \tilde{P}_{N}$ により調整することによ り極めて微小な破壊確率值の推定時の収束を速めること が可能となる.このように, 変換された確率測度 $\tilde{P}_{B}, \tilde{P}_{N}$ を重点サンプリング測度と呼ぶ.

\section{$6 \cdot 2$ 重点サンプリング測度の選定}

式 (28) で与えられるシミュレーションスキームを有効と するためには, $d P_{B} / d \tilde{P}_{B}$ を陽に表現できるような確率測

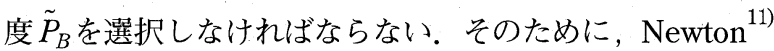
に従って，適当な可積分性を有する関数 $u(x)$ を用いて，

$$
\tilde{B}(x)=B(x)+\int_{x_{0}}^{x} u(\xi) d \xi
$$

により $B(x)$ から $\tilde{B}(x)$ に変換し，変換された $\tilde{B}(x)$ が確率 測度 $\tilde{P}_{B}$ 下で Wiener 場となるような測度 $\tilde{P}_{B}$ を選定する. このとき, Girsanovの定理 ${ }^{12)}$ により,$d P_{B} / d \tilde{P}_{B}$ は次式 で与えられる。

$$
\frac{d P_{B}}{d \tilde{P}_{B}}(\boldsymbol{B})=\exp \left\{\int_{x_{0}}^{x_{c}} u(x) d B(x)+\frac{1}{2} \int_{x_{0}}^{x_{c}} u(x)^{2} d x\right\}
$$

同様に，

$$
\tilde{N}=N+\gamma_{0}
$$

により $N$ から $\tilde{N}$ に変換し，確率測度 $\tilde{P}_{N}$ 下で $\tilde{N}$ が標準正 規確率変数となるように選定する。このとき， $d P_{N} / d \tilde{P}_{N}$ は次式で与えられることは容易に示すことができる。

$$
\frac{d P_{N}}{d \tilde{P}_{N}}(N)=\exp \left\{\gamma_{0} N+\frac{1}{2} \gamma_{0}^{2}\right\}
$$

式 (29)，式 (31) を式 (13) および式 (14) に代入すると, 重点サンプリング測度下で $C_{0}(x)$ の空間変動を記述する 確率微分方程式は次式のようになる。

$$
\begin{aligned}
d C_{0}(x)= & -\left\{\frac{1}{L_{C}} C_{0}(x)-\sqrt{\frac{2 \sigma_{C_{0}}^{2}}{L_{C}}} u(x)\right\} d x \\
& +\sqrt{\frac{2 \sigma_{C_{0}}^{2}}{L_{C}}} d \tilde{B}(x) \\
C_{0}\left(x_{0}\right)= & \sigma_{C_{0}}\left(\tilde{N}-\gamma_{0}\right)
\end{aligned}
$$

したがって,$u(x)$ および $\gamma_{0}$ を正の量とすることによって $C_{0}(x)$ の平均的挙動が負の值に低減されるため, 式 (16) の解である $T\left(x_{c}\right)$ が小さな值を取る確率が高まり, 結果 として破壊条件 $T\left(x_{c}\right) \leq t$ が成立する確率を高めることが 可能となる.

\section{$6 \cdot 3$ 最適制御量の選定法}

次に，文献 9) で著者が提案した手法に基づいて，最適 な $u(x)$ および $\gamma_{0}$ を導出する。まず，無限次元空間であ る関数空間を有限次元区間で近似するために，区間 $\left[x_{0}\right.$, $\left.x_{c}\right]$ 上に

$$
x_{k}=x_{0}+k \Delta x\left(\Delta x=\frac{x_{c}-x_{0}}{K} ; k=0,1, \cdots K\right)
$$

なるメッシュ点を設定し, Wiener 過程の増分列から

$$
\Xi_{k}=\left\{B\left(x_{k}\right)-B\left(x_{k-1}\right)\right\} / \sqrt{\Delta x}(k=1, \cdots K) \quad(36)
$$

を導入する. このとき， $\Xi_{l}, \cdots, \Xi_{K}, N$ の張る空間は互 いに独立な標準正規確率変数の空間となるので，これを 標準空間と呼ぶ.

式 (16) に対して適当な離散近似スキームを適用するこ 
とにより，T(x) に対する離散近似表式を標準空間上で表 現したものを形式的に $T\left(x_{c}\right)=\mathrm{G}\left(\Xi_{i}, \cdots, \Xi_{K}, N\right)$ と表 すことにすれば，式 (17) により，標準空間における破壊 領域の境界曲面，いわゆる限界状態曲面は，

$$
G\left(\Xi_{1}, \cdots, \Xi_{K}, N\right)-t=0
$$

で与えられる。この曲面上にあって, 原点からの最小距 離を与える点は 1 次近似 2 次モーメント法 ${ }^{13)}$ での設計点 に他ならず，これを求める問題は式 (37) の拘束下で $N^{2}$ $+\sum_{k=1}^{K} \Xi_{k}^{2}$ を最小化することに帰着される.

一方, 式 (29) の上記離散スキーム下での表示が,

$$
\tilde{\Xi}_{K}=\Xi_{k}+u\left(x_{k-1}\right) \sqrt{\Delta x}(k=1, \cdots, K)
$$

となることと, 式 (31) を考慮すると, 限界状態曲面の方 程式は,

$$
\begin{gathered}
G\left(\tilde{\Xi}_{1}-u\left(x_{0}\right) \sqrt{\Delta x} ;, \tilde{\Xi}_{K}-u\left(x_{K-1}\right) \sqrt{\Delta x},\right. \\
\left.\tilde{N}-\gamma_{0}\right)-t=0
\end{gathered}
$$

となる.この拘束下で設計点を求めるための最小化問題 の解が， $\widetilde{\Xi}_{k}=0(k=1 ， \cdots K), \tilde{N}=0$ で得られるように $u(x)$ および $\gamma_{0}$ が選定されているならば, 重点サンプリ ング測度下では丞拉よび $\tilde{N}$ が平均ゼロとなることから， 重点サンプリングシミュレーション下ではおよそ $50 \%$ の サンプルが破壊領域に達することになる。このときシミ ユレーションが効率的となることが経験的に知られてい ることから ${ }^{14)}$ この条件が満たされるような $u(x)$ および

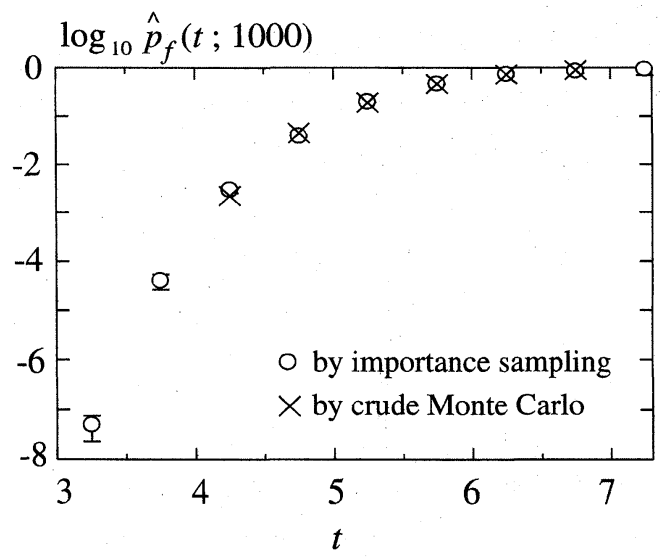

Fig. 3. Estimated probability of failure.

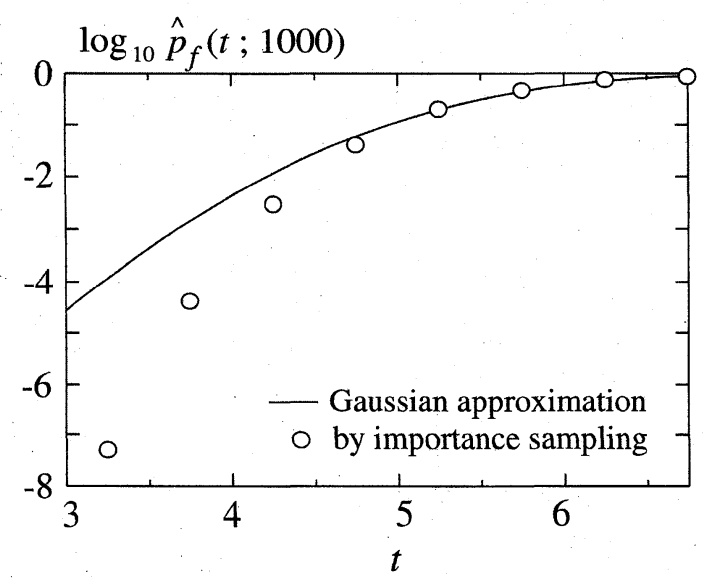

Fig. 4. Comparison with the Gaussian approximation. $\gamma_{0}$ を最適な制御量であると考える.

以上の議論に打いて, 離散近似スキームをもとの連続 スキームに極限移行させると, 途中の計算過程は省略す るが, 次のような条件付き変分問題を解くことに帰着さ れる。

$$
\begin{array}{ll}
\operatorname{minimize} & \gamma_{0}^{2}+\int_{x_{0}}^{x_{c}} u(x)^{2} d x \\
\text { subject to } & e^{-\sigma_{c_{0}}^{2} / 2} \int_{x_{0}}^{x_{c}} \frac{e^{-\beta(x)}}{g(x)} d x-t=0
\end{array}
$$

$$
\begin{aligned}
\beta(x)= & \sigma_{C_{0}} e^{-\left(x-x_{0}\right) / L_{C}} \\
& \times\left\{\gamma_{0}+\sqrt{\frac{2}{L_{C}}} \int_{x_{0}}^{x} e^{\left(\xi-x_{0}\right) / L_{C}} u(\xi) d \xi\right\}
\end{aligned}
$$

この変分問題を陽に解くことは難しいため，本論文では 未知関数 $u(x)$ の関数形として,

$$
u(x)=\left\{\begin{array}{cl}
\gamma_{0} / \sqrt{2 L_{C}} & \left(x_{0} \leq x<x^{*}\right) \\
0 & \left(x^{*} \leq x \leq x_{c}\right)
\end{array}\right.
$$

なる形に限定して考えることとする。もしも， $x^{*}-x_{0}$ が相 関距離 $L_{c}$ に比べて十分大きくなるように $x^{*}$ が選定され ていれば，十分よい近似で，

$$
u(x)=\left\{\begin{array}{cc}
\sigma_{C_{0}} \gamma_{0} & \left(x_{0} \leq x<x^{*}\right) \\
0 & \left(x^{*} \leq x \leq x_{c}\right)
\end{array}\right.
$$

となる。したがって，式 (43)，(44) を式 (40)，(41) に代 入することにより得られる最小化問題を解くことにより, 最適な $x^{*}, \gamma_{0}$ が得られる.

\section{$6 \cdot 4$ 数值例}

ここでは以上の議論に基づいて構成した重点サンプリ ング法を実際に適用し，その有効性を確認する。Fig. 3 は重点サンプリングシミュレーションにより算出した破 壊確率の推定值 $\hat{p}_{f}(t ; N)$ をいくつかの $t$ の值に対して対 数プロットしたものである。ここでパラメータ值は前節 での議論を参考として $, \sigma_{C}=0.25, L_{C}=0.25, m=$ $2.929, x_{0}=0.05, x_{c}=1.0$ と設定し, 補正関数 $F_{I}$ として は， $W / a_{r}=2.5 x_{c}$ として式 (26) を用いてある. また式 (13), (16) の数值解法としては, メッシュサイズ $\Delta x=$ $4.75 \times 10^{-4}$ の確率的 Euler 法を用いてある. 図中○印は 重点サンプリング法による推定值を示し，比較のため同 じサンプル数で行なった直接モンテカルロ法の結果を ×印で示してある.ここではサンプル数を $N=1000$ とし たシミュレーションを独立に 10 回行ない, その平均によ り推定值を導出し，その標準偏差の幅を図中エラーバー により表示してある.この結果から, 確率が $10^{-6}$ を下回 るような場合でも，重点サンプリング法による推定での 標準偏差幅は十分に小さくなっており，この程度のサン プル数でも十分よい精度が得られていると考えられる。 これに対し，直接サンプリング法では同程度のサンプル数 では $10^{-3}$ 程度が推定限界であり，この例では $T<4$ では 推定值がゼロとなってしまっている.

Fig. 4 は Fig. 3 と同じパラメータ設定の下, 文献 7) に打いて提案された Gauss 近似による結果との比較を示 したものである. Gauss 近似とは, 相関距離が小さい場 合に中心極限定理の効果により $T\left(x_{c}\right)$ の分布が正規分布 で近似し得るとするもので，何らかの理論的根拠を伴う 
解析的方法はこれ以外には得られておらず，また文献 7) では, 残存寿命分布の平均近傍ではよい近似が得られる ことが確認されている. 図中○印は重点サンプリング法 による推定結果を, 実線は Gauss 近似による破壞確率の 近似評価を表しているが，この結果から Gauss 近似は破 壊確率が $10^{-2}$ 程度まではよい精度を与えるが，実用上重 要となるそれよりもはるかに小さな破壊確率を与える時 間領域では次第に精度が低下していくことがわかる。し たがって, 本研究で構築した重点サンプリング法の適用 は，実用的観点から見ても必要不可欠であると言ってよ いであろう。

\section{7 結言}

本論文では, き裂進展抵抗の空間的不規則変動を連続 確率場を用いて数学的にモデル化することにより，新し い不規則き裂進展モデルを提案し，その妥当性について 実験データとの比較を通じて検討すると共に, きわめて 微小な破壊確率值を効率的に推定することが可能な重点 サンプリングシミュレーションスキームを構築した。得 られた主な結果は以下の通りである。

- 本研究で提案する確率モデルにより, 統計的疲労 試験における残存寿命の確率的性質をよく再現す ることができることを明らかとした．

- 提案モデルに打ける破壞確率の推定に対して, Girsanovの定理を活用した重点サンプリングシミ ユレーションスキームを構成し, 極めて小さな破 壊確率值を少ないサンプル数で精度よく推定し得 ることを明らかとした。
本研究の遂行にあたり，京都大学大学院生古川昌彦氏 より多大なる助力を得ましたことを記し，謝意を表しま す。また本研究の一部は文部省科学研究費 (奨励研究 (A) 11750057）の補助の下に行なわれたことを記し，併 せて謝意を表します。

\section{参 考 文 献}

1) 市川昌弘, 浜口光夫, 中村武夫, 材料, 33, 8 (1984).

2) 市川昌弘, 中村武夫, 材料, 34, 321 (1985).

3) 市川昌弘, 秋田 敏, 材料, 35, 1177 (1986).

4) 市川昌弘, 中村武夫, 材料, 35, 1272 (1986).

5) 石川、浩, 鶴井 明, 日本機械学会論文集, A-50, 1309 (1986).

6) 田中泰明, 鶴井 明, 第 12 回材料・構造信頼性シンポジ ウム講演論文集, 113 (1993).

7) 田中泰明, 西島康則, 第 13 回材料・構造信頼性シンポジ ウム講演論文集, 20 (1994).

8）板垣浩, 石塚鐵夫, 黄 培彦, 日本造船学会論文誌, $\mathbf{1 6 5}$, 253 (1990).

9) 'H. Tanaka, "Structural Safety and Reliability" (Proc. of ICOSSAR '97), p.411 (1998) Balkema, Rotterdam.

10) J. L. Doob, Annals of Math., 43, 351 (1942).

11) J. Newton, SIAM. Appl. Math., 54, 1780 (1994).

12) I. V. Girsanov, Theory Probab. Its Appl., 5, 285 (1960).

13）例えば, G. I. Schuëller (小西他訳), “構造物の安全性と 信頼性”（1984）丸善.

14) G. I. Schuëller and R. Stix, Structural Safety, 4, 293 (1987). 